UDC 699.86:697.1:696.48

\title{
Estimating the effects of reducing energy consumption for buildings heating
}

\author{
A. Lis \\ EngD, Częstochowa University of Technology, Częstochowa, Poland, anna.lis@pcz.pl, ORCID: 0000-0001-9497-5754
}

\begin{abstract}
Maintaining the current level of production and living standards, while caring for the environment and good health condition of societies, is possible due to rational management of energy resources and proper shaping of the energy performance of erected buildings, as well as improving the characteristics of existing buildings. The essence of implementing a deep thermal modernization program for existing buildings is to achieve benefits, not only economic but also environmental, functional, community, social, integration and others. About $70 \%$ of energy in the buildings is consumed for heating and hot water preparation. Households are the largest heat consumers. In the article, the analysis of the effects of heat consumption reduction was performed for residential buildings. The basic effects of conducted thermal modernization relate to economic issues associated with the reduction of fuel, water and electricity consumption, and thus incurred fees. The effects also refer to reducing the amount of air pollution, improving indoor microclimate conditions and user safety, as well as eliminating energy poverty and stimulating public awareness of energy-saving activities.
\end{abstract}

Keywords: energy consumption, energy efficiency, air pollution, indoor microclimate conditions.

Introduction. The increase in energy consumption in recent years has led to a significant depletion of natural resources and environmental pollution. In Europe, the implementation and operation of buildings consume $40 \%$ of total energy consumption and in the United States about $65 \%[1,2,3]$. This energy consumption in Europe causes $36 \%$ of greenhouse gas emissions to the atmosphere and in the United States - about $30 \%$ [1, 2, 3]. About $70 \%$ of the energy in a building is consumed for heating and hot water preparation [1]. From among approximately 200 million buildings operated in the European Union, a large part of them was built before 1990. Their low thermal insulation is the reason for significant energy consumption. In the framework of the development of European Union countries, there are aims to:

- increase energy efficiency;

- reduce greenhouse gas emissions;

- implement a low carbon policy;

- increase the share of renewable energy in overall energy consumption [5-8].

Member States of the European Union have made a commitment compared to the levels of 1990 to $[9,10]$ :

- increase energy efficiency by $20 \%$

- reduce greenhouse gas emissions by $20 \%$

- increase the share of renewable energy sources in final energy consumption by $20 \%$ by 2020 .

The share of energy consumption for heating in the overall energy consumption balance is steadily decreasing, in recent years, which is associated with the introduction of increasingly stringent requirements in terms of thermal insulation and energy-efficiency, installation of more efficient heating devices and intensification of activit- ies in the field of thermal modernization of buildings. It is estimated that the annual energy savings achieved through thermal modernization may in 2030 reach $26 \%$ of consumption from 2013 [11].

Implementation of the energy efficiency program brings measurable benefits. Fig. 1 presents cumulated energy savings since 2000 , which illustrate how much higher energy consumption would be in a given year if improvements in energy efficiency were not introduced [12]. According to expert estimates from Buildings Performance Institute Europe, the total net social benefits of implementing a deep thermal modernization program by 2045 could reach about 170 billion euros [11].

Starting from 2021, all newly constructed buildings will require very low energy, covered mainly by renewable resources. The share of energy from renewable sources is steadily increasing (Fig. 2.) Renewable energy can supply two-thirds of the total global energy demand, and contribute to the significant greenhouse gas emissions reduction [13-16]. Using new datasets for renewable energy, the technical and economic possibilities of accelerating the implementation of this type of energy to 2050, were tested. The share of renewable energy in total primary energy supply would rise from $14 \%$ in 2015 to $63 \%$ in 2050 . The share of renewable energy in the power sector would increase from $25 \%$ in 2015 to $85 \%$ in 2050 . Energy efficiency, lowcarbon economy, and renewable energy would result in emissions reductions of $48-58 \%$ by 2030 and $95 \%$ by 2050 . It has been also estimated that the potential for reducing carbon dioxide emissions in the operation of buildings up to 2030 is 3,7 Gt. Percentage share in each region is shown in Fig. 3 [7, 13-16]. 
Mtoe

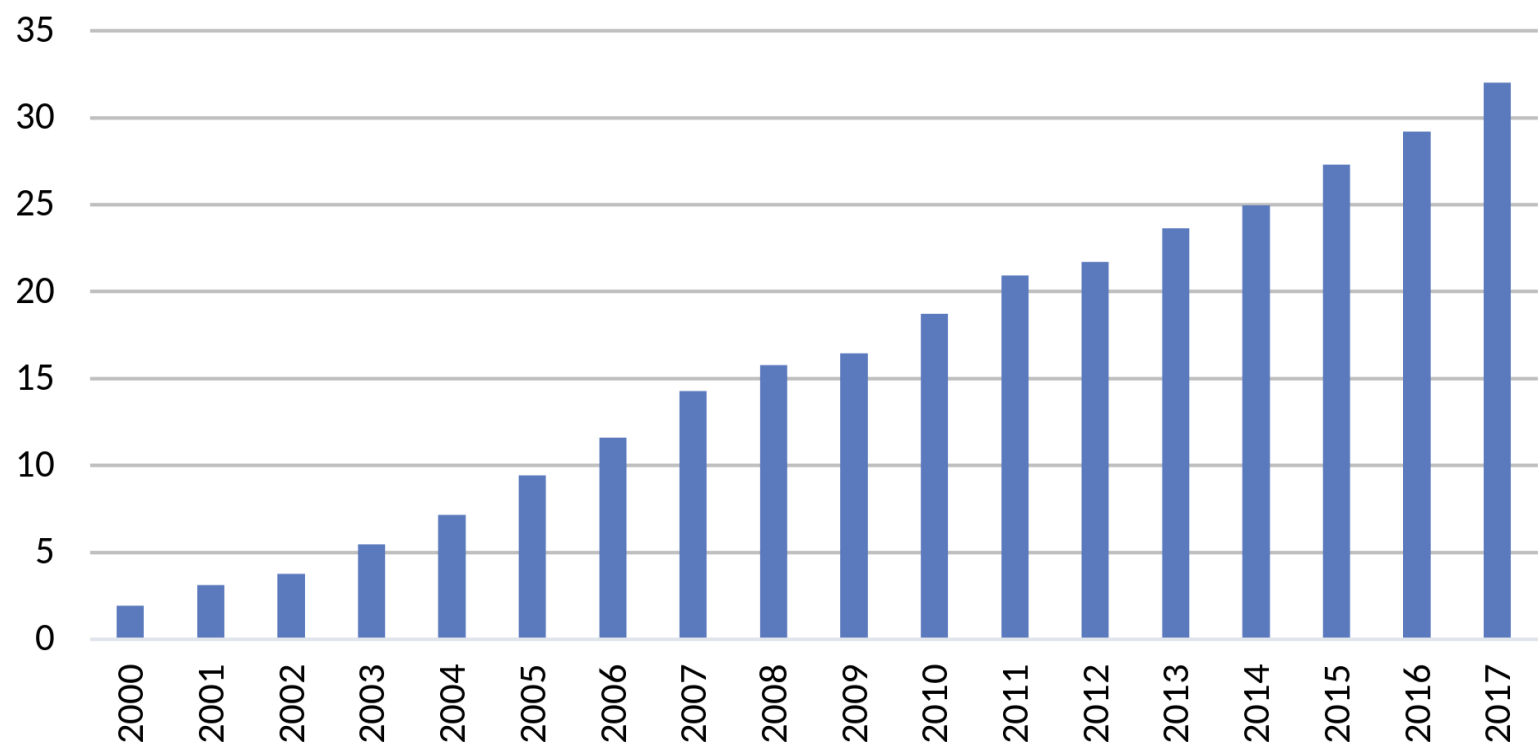

Fig. 1. Cumulated energy savings [12]

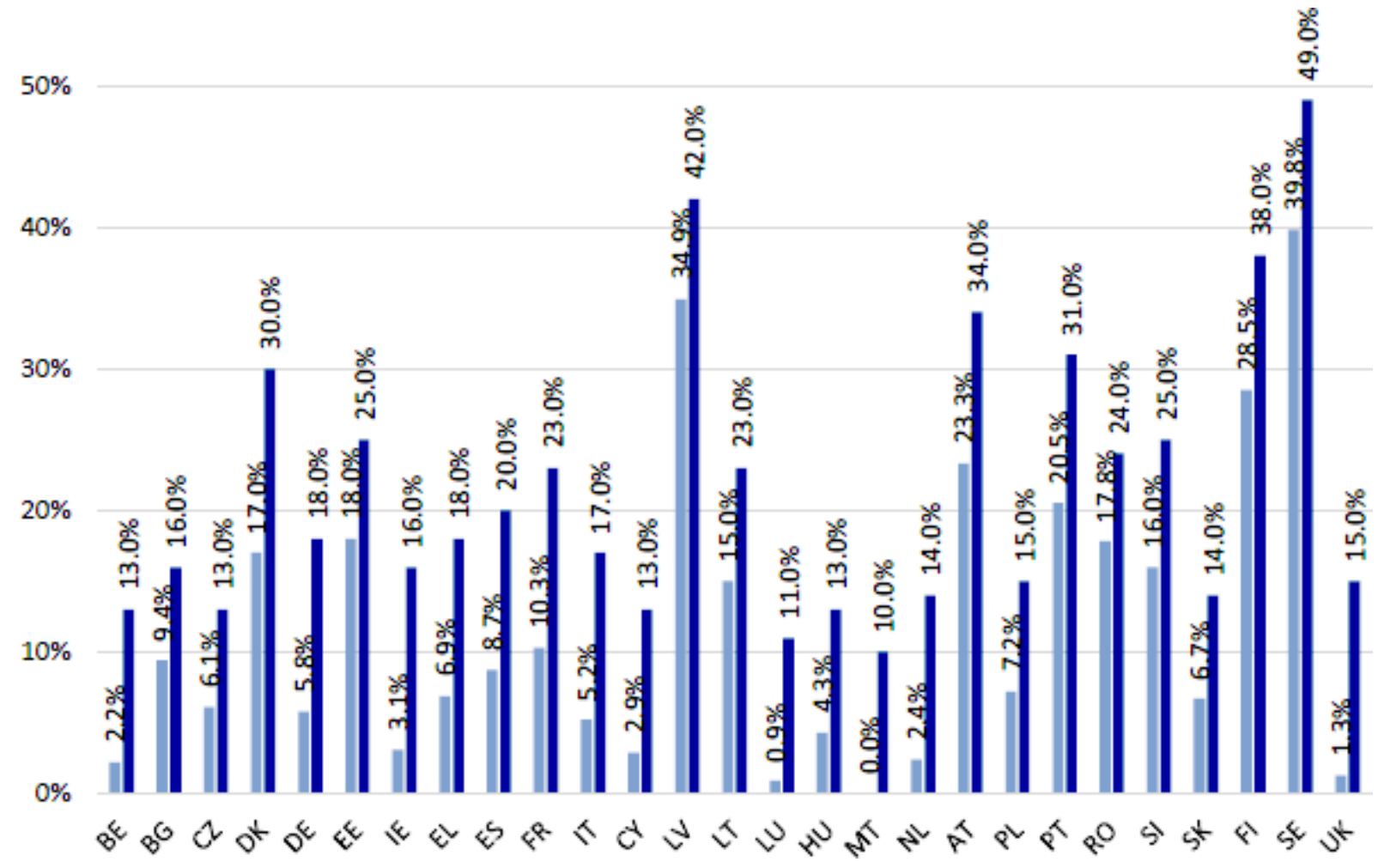

Fig. 2. Share of energy from renewable sources [13-14]:

- - share of energy from renewable sources in gross final consumption of energy, 2005;

- - target for share of energy from renewable sources in gross final consumption of energy, 2000 


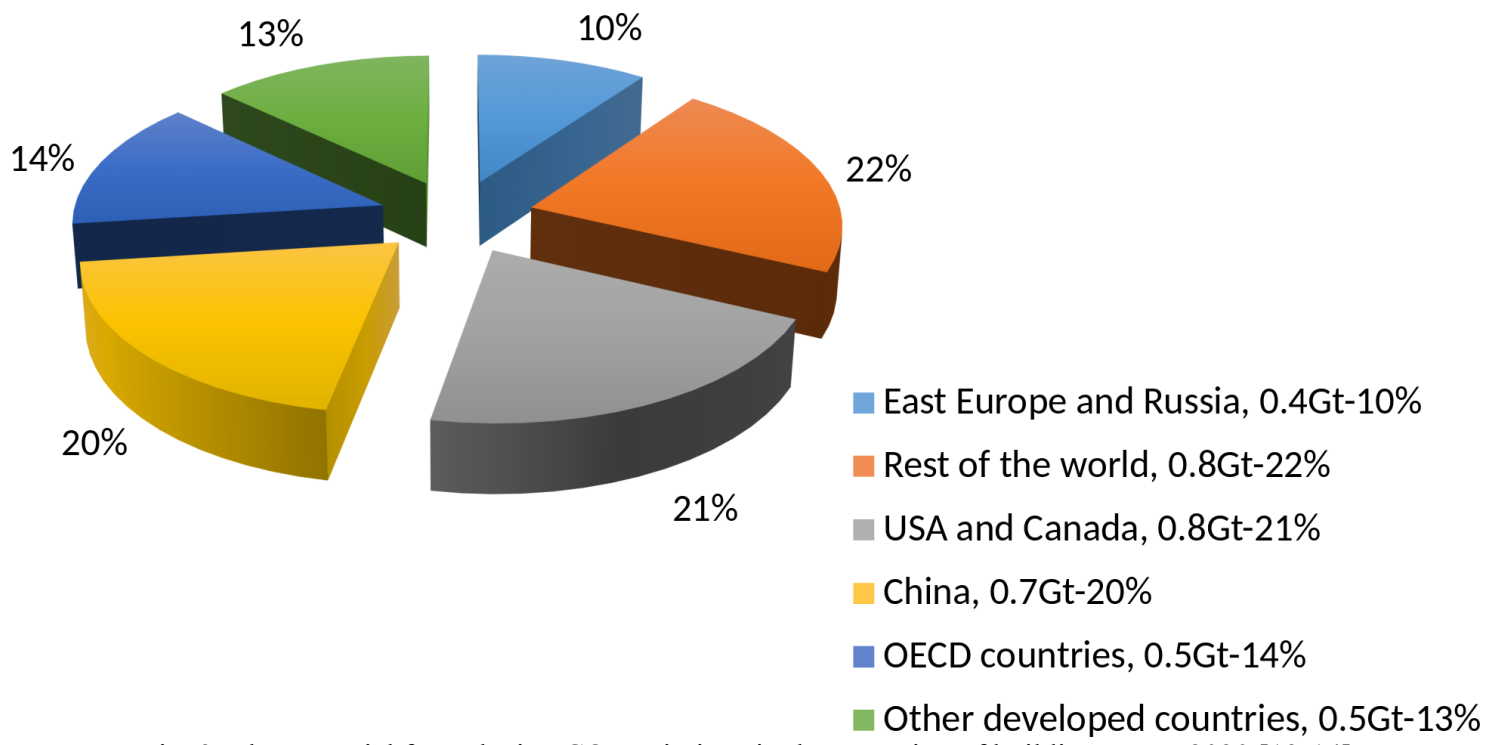

Fig. 3. The potential for reducing $\mathrm{CO}_{2}$ emissions in the operation of buildings up to 2030 [13-14]

Reducing energy consumption by introducing innovative technologies and solutions and adapting existing buildings to energy-saving construction standards combines energy and economic effects with care for the health and comfort of users and limiting the negative impact of buildings on the environment and climate.

It is estimated that households are the largest heat consumers, their share in the heat consumption market is about 50\% [17]. Bearing in mind the implementation of energy efficiency and the principles of sustainable development in building construction, the effects of reducing energy consumption in the group of 9 residential buildings were analysed.

In Poland, there are about 6 million buildings. About $85 \%$ of them are characterized by significant heat losses due to inappropriate thermal insulation of individual building envelope [18]. About $60 \%$ of heating and $70 \%$ of hot water preparation in these buildings is carried out from individual sources based on solid fuels [19]. It is mainly coal (domestic fuel), which often is poor quality. This results in a significant emission of air pollutants into the atmosphere. Therefore, air quality in Poland continues to give cause for severe concern [20]. As air quality declines, the risk of stroke, heart disease, lung cancer, chronic and acute respiratory diseases, including asthma, increases. Air pollution shortens the lives of the average European Union citizen by more than 8 months. For the Polish residents, this value increases by 1-2 months. It causes the premature death of about 46,000 people in Poland every year $[21,22]$. This is 10 times more than in the case of road accidents. Households have been causing $55 \%$ particulate matter PM 2.5 and 23\% nitrogen oxides emissions in recent years [23].
Purposes of the article. Given the significant heat consumption in residential buildings and their negative impact on the environment, particularly due to low carbon emissions and the phenomenon of smog, including this group of buildings in the program of deep thermal modernization should bring measurable benefits resulting from the reduction of energy consumption. This will not only economic but also the environmental, utility, and social benefits [11, 24-27].

Estimated buildings. The group of analysed buildings are multi-family residential, built in the 1950s and 1960s. The buildings were made in traditional technology with brick walls and precast beam and hollow tile ceiling. The buildings were 3 and 4 storeys. They have a complete basement and an unused attic. Although the structural elements were intact, the general technical condition of the buildings was poor. First of all, the façades were damaged. There were numerous defects in the external plaster and flashings. Old wooden windows and doors were characterized by low insulation and tightness. The installations were outdated and inefficient. There was a lack of patency of some chimney and ventilation ducts. The absence of thermal insulation, both in the walls and ceilings, resulting in significant heat loss. Heating of buildings and preparation of hot water was mainly based on solid fuels.

Based on auditing analysis, the actions to deep thermal modernization in the studied buildings were taken. Insulation of partitions using mainly polystyrene and mineral wool and replacement of wooden windows for modern UPVC windows and doors, as well as modernization of the heating and hot water preparation system were carried out. The values of heat transfer coefficients for building envelope before and after 
thermal modernization are presented in Table 1. Two buildings were already connected to the central heat network, three - to the local heat network. They had gas water heaters. The others equipped by individual heating and hot water preparation. In buildings with individual heating, the creation of own boiler rooms, central heating system and preparation of hot water was proposed. In addition, during the thermal modernization, the works should include the necessary overhaul of the cold water and sewage system, as well as, defective ventilation must be cleared.

Energy and economic effects. The economic benefits resulting from the energy effects associated with the reduction of fuel, water and electricity consumption are, above all:

- the reduction of charges incurred for the use of buildings;

- the increase in economic development in sectors related to thermal modernization, which causes the creation of new jobs;

- reduction of expenses for improvement of public health and the state and protection of the environment.

As a result of the thermal modernization, the final energy demand for heating, ventilation and hot water preparation decreased by in the range of $35-65 \%$. Before thermal modernization, the final energy demand for heating and hot water preparation was on average $186.4 \mathrm{kWh} /\left(\mathrm{m}^{2}\right.$.year $)$ at standard deviation $54.6 \mathrm{kWh} /\left(\mathrm{m}^{2} \cdot\right.$ year $)$. After thermal modernization, it will be decreased to $89.6 \mathrm{kWh} /\left(\mathrm{m}^{2} \cdot\right.$ year $)$ on average at standard deviation $21.3 \mathrm{kWh} /\left(\mathrm{m}^{2} \cdot\right.$ year $)$.

The average usable floor space of a flat in Poland is $78.2 \mathrm{~m}^{2}$. The average annual energy consumption in a household is $84 \mathrm{GJ}$ and its cost is about 1000 euros [17]. Due to the steady in- crease in the costs of fuels and energy, there is a continuous increase in the costs of operating buildings. However, measurably skipping the thermal modernization program would increase these costs. Especially, the replacement of coal into gas fuel may not cause measurable economic benefits. However, it will significantly reduce low-carbon emissions and costs associated with coal boiler operation.

Reduction of energy demand in the analysed group of buildings will cause an average of about $40 \%$ decrease in fees. After thermal modernization the consumption of water decreased by about $10 \%$, and also the electricity of about $26 \%$, certainly due to the lack of necessity to reheat the rooms and the use of energy-saving lighting.

Environmental effects. Environmental benefits are associated with the reduction of emissions into the atmosphere of harmful substances from the combustion of fuels, primarily solid, used to generate energy. The substances lead to:

- negative changes in the Earth's climate

- deterioration of the quality of life

- problems of human health

- increase in mortality.

Harmful substances for humans that especially increase the risk of cardiovascular and respiratory diseases or death are [28, 29]:

- above all particulate matters PM10 and PM2.5;

- polycyclic aromatic hydrocarbons, e.g. benzo(a)pyrene, dioxins;

- sulphur dioxide;

- nitrogen oxides;

- carbon monoxide;

- carbon dioxide;

- heavy metals.

Heat transfer coefficient of analysed buildings (own research)

\begin{tabular}{|l|c|c|c|c|}
\hline \multirow{2}{*}{ Building envelope } & \multicolumn{4}{|c|}{ Heat transfer coefficient, W/(m $\left.{ }^{2} \mathrm{~K}\right)$} \\
\cline { 2 - 5 } & \multicolumn{2}{|c|}{ Before thermal modernization } & After thermal modernization \\
\cline { 2 - 5 } & Harmonic mean & Standard deviation & Harmonic mean & Standard deviation \\
\hline Walls & 1.32 & 0.18 & 0.22 & 0.03 \\
\hline Ceilings under attics & 1.47 & 0.34 & 0.17 & 0.02 \\
\hline Ceilings above basements & 1.29 & 0.25 & 0.32 & 0.06 \\
\hline Windows & 2.50 & 0.40 & 1.60 & 0.20 \\
\hline Doors & 3.42 & 0.59 & 2.53 & 0.86 \\
\hline
\end{tabular}


Poor air quality is particularly troublesome during the heating season. Pollutants introduced into the air as a result of emissions accumulate around the place of their production and are, under unfavourable weather conditions, the cause of the formation of smog.

Reduction of energy demand leads to decreasing the amount of fuel necessary to it produce (hard coal was accepted for district heating). This causes a reduction of burdensome emissions into the atmosphere of harmful substances arising in the process of fuel combustion. This is particularly beneficial for individual boiler rooms. The percentage reduction in emissions of individual harmful substances into the atmosphere when leaving coal as an energy source after thermal modernization is shown in Fig. 4. The use of gas will result in an almost $98-100 \%$ reduction of pollution into the atmosphere.

Usable effects. The utility benefits are associated with the improvement of the quality of the indoor environment, thermal comfort and living comfort. An improper condition of the indoor environment can lead to the phenomenon of sick building syndrome. Prolonged stay in such an environment causes and intensifies the symptoms associated with the malfunctioning of the body and leads to its weakness or disease. The results of research conducted among residents regarding the conditions of interior microclimate and thermal comfort of people also indicate a significant improvement in the room's environmental conditions and the feelings associated with being in them. An increase in indoor air temperature and a decrease in air humidity were observed. High humidity due to energy-saving (low internal temperature) is unfavourable due to growth of fungi, which releases carcinogenic mycotoxins, and damage of internal surface finishing.

The conditions of the thermal comfort of the inhabitants were also radically improved. Before carrying out thermal modernization works, as much as $71 \%$ of residents indicated the inadequate condition of the indoor environment (Fig. 5). During the research, the sick building syndrome symptoms were noted in people staying in the rooms, which they identified with longterm staying in a given environment. The study was based on questionnaires. The occurrence of symptoms in the studied respondents before and after thermal modernization is presented in Table 2.

Some of the sick building syndrome symptoms such as above all flu-like symptoms or nose irritation and rhinitis partly receded after thermal modernization. Increased fatigue, sleepiness and difficulty in concentration which may be related to overheating of the rooms, excessive tightness of windows or the growth of the level of carbon dioxide in the rooms. An important aspect of thermal modernization, especially in buildings with a low technical standard, is the increase in the value of housing resources and the building itself, as well as their attractiveness related to the possible sale as well as the aesthetics of the building and its surroundings.

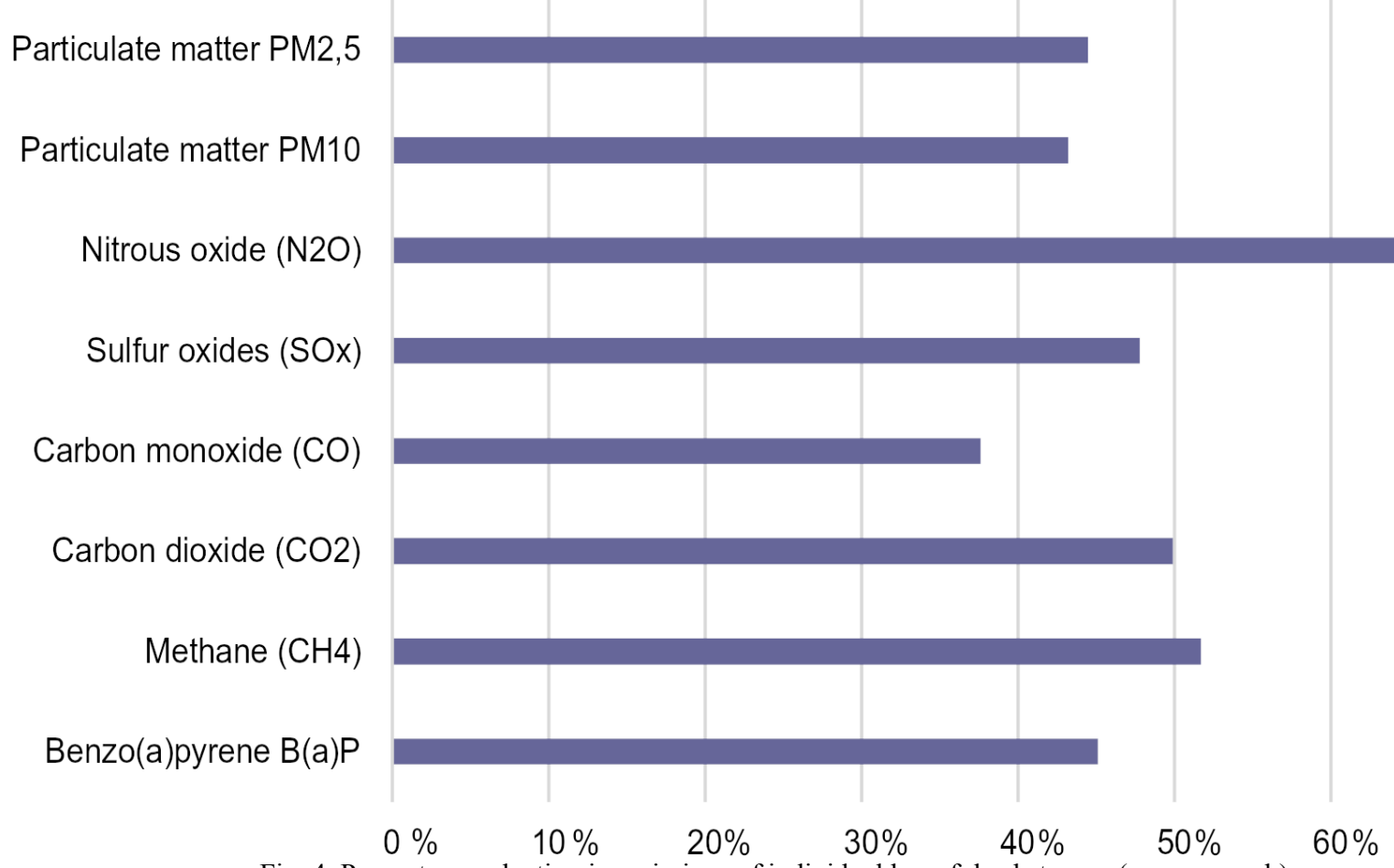

Fig. 4. Percentage reduction in emissions of individual harmful substances (own research) 


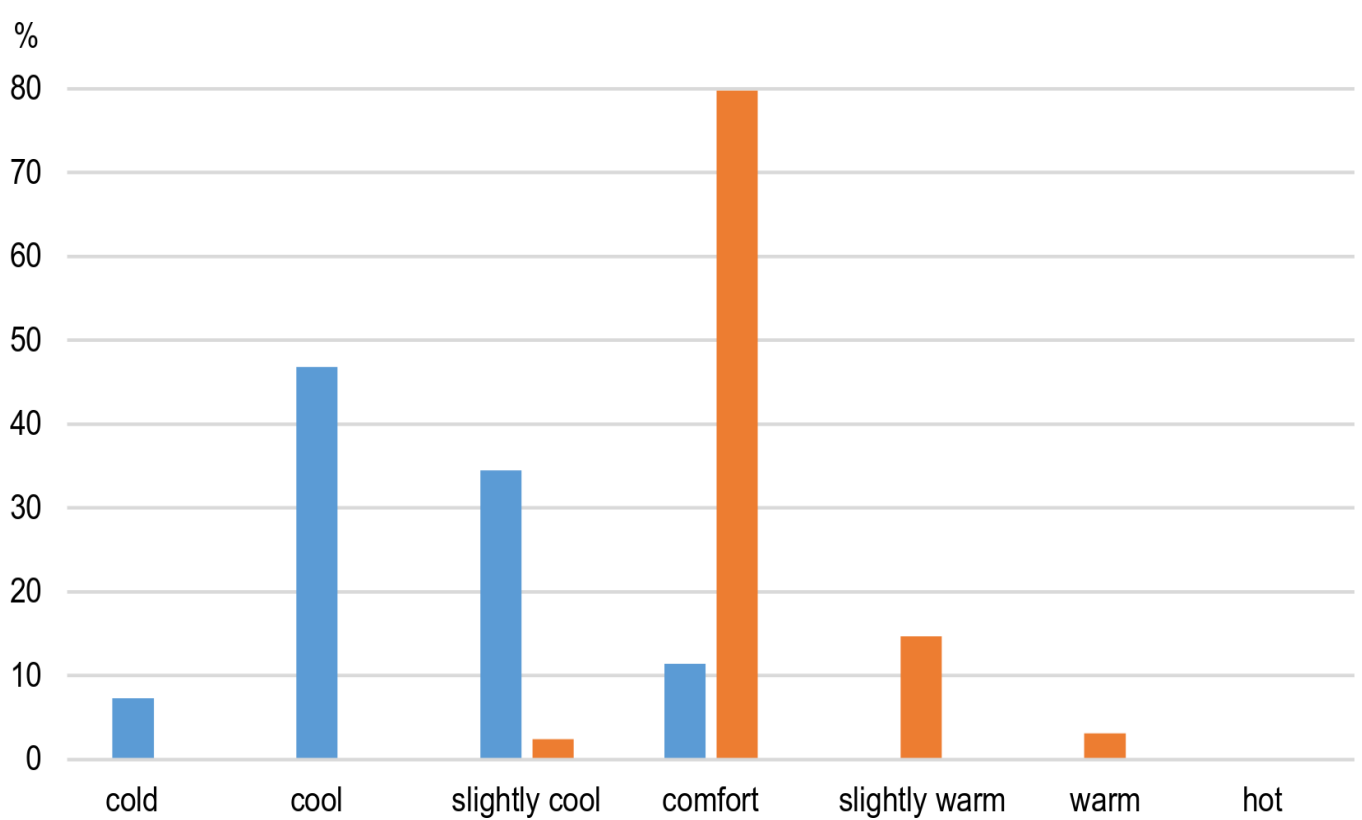

Fig. 5. Percentage of thermal fillings of respondents before and after thermal modernization (own research):

- before thermal modernization;

n- share of energy from renewable sources in gross final consumption of energy, 2005;

- after thermal modernization

Sick building syndrome symptoms before and after thermal modernization [own research]

\begin{tabular}{|l|c|c|}
\hline \multirow{2}{*}{ Sick building syndrome symptoms } & \multicolumn{2}{|c|}{ Symptom occurrence, \% } \\
\cline { 2 - 3 } & before thermal modernization & after thermal modernization \\
\hline Eye irritation & 21.6 & 7.4 \\
\hline Throat irritation, cough & 46.7 & 17.5 \\
\hline Nose irritation, rhinitis & 39.5 & 25.6 \\
\hline Headache & 35.6 & 30.4 \\
\hline Itching and dry skin & 14.1 & 11.2 \\
\hline Flu-like symptoms & 29.2 & 9.9 \\
\hline Malaise & 37.9 & 17.4 \\
\hline Difficulty in concentration & 26.7 & 42.1 \\
\hline Fatigue and sleepiness & 23.6 & 41.2 \\
\hline
\end{tabular}

As a result of the thermal modernization, there was an improvement in safety related to the elimination of individual heating sources and the risk of poisoning from inefficient smoke and ventilation ducts. In individually heated buildings, the creation of a central heating system and hot water preparation has contributed to the improvement of the standard of flats and the quality of their use, which is especially important for the elderly.

The elimination of individual heating sources has contributed to increasing the cleanliness of the rooms and reducing the costs of renovating them. In general, residents rated the quality of indoor before thermomodernization as unsatisfactory $(51.3 \%)$ and poor $(12.3 \%)$. After the thermal modernization, the majority of residents assessed the quality of the indoor environment as very 
good.

As a result of the renovation of the façade, thermal modernization activities brought an aesthetic effect. It was further strengthened as a result of ordering the environment and its greening, made thanks to the involvement of the residents themselves. The works improve the standard of the apartments and the whole building, contributing to the increase in the value of the apartments as well as the attractiveness for their sale.

Social effects. Social benefits are primarily associated with the reduction of energy poverty, stimulating public awareness of energy-efficient activities and the phenomenon of social exclusion due to the poverty. Conducting activities related to deep thermal modernization of the building structure, especially within degraded areas, can be a positive element conducive to urban regeneration.

Conducting a deep thermal modernization of a building allowed reducing the costs associated with its operation, which undoubtedly improves the financial situation of the poorer residents. An increase in fuel prices could lead these inhabitants to energy poverty, which occurs when the costs of ensuring an adequate indoor temperature in winter and summer exceed $10-20 \%$ of the household budget.

Preparation, implementation and use of the results of a thermal modernization project may also result in many of beneficial elements in the area of functioning of the local community. The social awareness and activity of the inhabitants are stimulated. They are more willing to take care of the common property, which is the renovated building.

The implementation of energy-efficient solutions favours the energy-saving and ecological attitude of residents and is a model for the owners of neighbouring residential buildings. Exemplarily implemented thermal modernization projects can become an impulse to stimulate this type of activities among building owners and administrators, especially in smaller, often more integrated local communities.

Conclusions. Maintaining the current level of production and living standards, while caring for the environment and good health condition of societies, is possible due to rational management of energy resources and proper shaping of the energy performance of erected buildings, as well as improving the characteristics of existing buildings, taking into account the economic, environmental and social efficiency of the conducted projects.
Such activities perfectly fit into the idea of sustainable development, which assumes satisfying the basic needs of society as well as preserving, protecting and restoring the proper condition of the natural environment of the Earth. Conducting deep thermal modernization not only allows for rationalization of energy consumption or reduction of building operation costs but at the same time minimizes the harmful impact of the building on the environment, resulting from the use of natural resources and the emission of harmful substances generated in the process of fuel combustion to the atmosphere, improves the condition of the interior environment, increases its comfort use and brings numerous benefits in the social sphere. The article presents the results of thermal modernization activities carried out in a group of multi-family residential buildings. The problem of non-compliance with applicable requirements in the field of thermal protection of buildings is extremely important as it currently concerns a significant part of existing housing resources. In addition to the economic benefits resulting from the obtained energy effect, thermal modernization activities have contributed to the improvement of the outside air quality, interior microenvironment and thermal comfort of people, as well as to the increase in the standard of use of buildings and the quality of life of their residents. Improving the comfort and safety of use is important especially for people in elderly age, who are often the majority of residents of buildings with particularly unfavourable energy parameters. Creating one boiler room in a building prevents the combustion of all kinds of plastics or rubber waste, so commonly practised by individual furnace users, which is a source of highly toxic, polycyclic aromatic hydrocarbons, dibenzofurans or dioxins. This contributes to the increase of ecological awareness of the local community in the scope of reducing environmental pollution by combustion products during the heating of buildings. Thermal modernization was particularly beneficial for people with lower incomes. Conducting thermal modernization allows radical reducing of operating costs, and thus, improve the financial situation of poor social groups, eliminates the phenomenon of energy poverty, and also increases the value of an owned property. An underestimated effect of thermal modernization was also the possibility of a beneficial effect on the consolidation and stimulation of the activity of local communities. Thermal modernization can also be an impulse to undertake revitalization activities. 


\section{References}

1. European Commission, Energy, https://ec.europa.eu/energy/en.

2. United States Department of Energy, https://www.energy.gov/.

3. Worldwatch Institute, https://www.worldwatch.org.

4. United States Environmental Protection Agency, https://www.epa.gov/.

5. Market Report Series: Energy Efficiency 2018. Analysis and Outlooks to 2040. International Energy Agency, 2018.

6. Global energy transformation: A roadmap to 2050. International Renewable Energy Agency, Abu Dhabi, 2019.

7. Communication from the Commission to the European Parliament, the Council, the European Economic and Social Committee and the Committee of the Regions. A Roadmap for moving to a competitive low carbon economy in 2050. European Environment Agency, Brussels, 2011.

8. Bukowski M. (eds.) 2050.pl journey to a low-carbon future. Temperowka, Warsaw, 2013.

9. Directive 2012/27/EU of the European Parliament and of the Council of 25 October 2012 on energy efficiency.

10. EUROPE 2020. A strategy for smart, sustainable and inclusive growth. Communication from the European Commission, Brussels, 2010.

11. Guła A. et al. Buildings modernisation strategy: Roadmap 2050. Institute of Environmental Economics, Cracow, 2014.

12. Energy efficiency in the period of 2007-2017, Statistical Information and Elaborations, Central Statistical Office, Warsaw, 2019.

13. Market Report Series: Renewables 2018. Analysis and Forecasts to 2023. International Energy Agency, 2018

14. Renewable Energy Statistics 2019.The International Renewable Energy Agency, Abu Dhabi, 2019.

15. Energy from renewable sources in 2017. Statistical Information and Elaborations, Central Statistical Office, Warsaw 2018.

16. Gielena D., Boshell F., Saygin D., Bazilian M. D., Wagner N., Gorini R. "The role of renewable energy in the global energy transformation." Energy Strategy Reviews. 2019. Vol. 24. pp. 38-50. https://doi.org/10.1016/ j.esr.2019.01.006

17. Energy consumption in households in 2015. Statistical Information and Elaborations, Central Statistical Office, Warsaw 2017.

18. Apartments. National Census of Population and Apartments 2011. Central Statistical Office, Warsaw, 2013.

19. Lohse R., Zhivov A. Deep Energy Retrofit Guide for Public Buildings: Business and Financial Models. Springer, Switzerland, 2019.

20. The state of the environment in Poland. Report 2018. The Chief Inspectorate for Environmental Protection, Warsaw, 2018.

21. Maas R., Grennfelt P. Towards Cleaner Air, Scientific Assessment Report. Narayana Press, Oslo, 2016.

22. Air quality in Europe - 2018 report. EEA, Luxembourg, 2018.

23. The Environmental Implementation Review 2019. Country Report - Poland. European Union, 2019.

24. Krawczyk D. A. Buildings 2020+. Constructions, materials and installations. Printing House of Bialystok Univesity of Technology, Bialystok, Cordoba, Vilnius, 2019.

25. Dubrakova K. "Optimization of thermal modernization of a group of buildings using simulation modeling." Journal of Applied Engineering Science. 2019. Vol. 17. no. 2. pp. 192-197. https://doi.org/10.5937/jaes17-21683

26. Lis. P. "Energy saving and reduction of emissions in heating residential buildings in Poland - potential and selected activities." E3S Web of Conferences. 2019. Vol. 116. Article Number 00044. 8 p. https://doi.org/10.1051/e3sconf/ 201911600044

27. Apatenko T., Bezlyubchenko O., Zavalniy O. "Energy modernization of residential houses as a challenge of modern.” Scientific Journal ScienceRise. 2018. no. 12. pp. 6-18. https://doi.org/10.15587/2313-8416.2018.153368

28. Environment. Statistical analyses. Statistics Poland, Warsaw, 2018

29. Gurjar B.R., Molina L.T., Ojha C.S.P. (eds.) Air Pollution, Health and Environmental Impacts. CRC Press, New York, 2010. 
УДК 699.86:697.1:696.48

\title{
Оцінка ефектів зменшення споживання енергії для опалення будівель
}

\author{
А. Ліс \\ к.т.н.,. Ченстоховський політехнічний університет, Ченстохова, Польща, anna.lis@pcz.pl, ORCID: 0000-0001-9497-5754
}

\begin{abstract}
Анотаиія. Збереження поточного обсягу $і$ якості виробництва, рівня життя при дбайливому ставленні до навколишнього середовища, а також забезпечення здоров'я суспільства можливе завдяки рачіональному управлінню енергоресурсами і правильному формуванню енергетичної характеристики зведених будинків, а також поліпшення енергетичних властивостей наявних будівель. Суть реалізачії програми глибокої термомодернізачії наявних будівель полягає в досягненні не тільки економічних, але й екологічних, функціональних, соціальних, інтеграційних та інших позитивних ефектів. Близько $70 \%$ енергії в будівлях використовується для опалення та виробництва гарячої води. Домашні господарства є найбільшими споживачами теплоти. У статті аналізується вплив зниження споживання теплоти на експлуатачійні характеристики будівлі. Основні економічні ефекти термомодернізаціі пов'язані зі скороченням споживання палива, води й електроенергії, а отже, фінансовими витратами. Наведені ефекти також пов'язані зі зменшенням забруднення повітря, поліпшенням умов мікроклімату в приміщеннях $i$ безпеки користувачів, а також усуненням енергетичної бідності і підвищенням обізнаності суспільства в галузі енергоефективності. У статті представлені результати заходів з модернізачіï, проведених у групі багатоквартирних житлових будинків. Проблема невідповідності чинним вимогам у галузі теплозахисту будівель $\epsilon$ надзвичайно важливою, оскільки наразі стосується значної частини наявних житлових ресурсів. Окрім економічних вигод від отриманого енергетичного ефекту, теплові модернізації сприяли покращенню якості зовнішнього повітря, мікроклімату та теплового комфорту людей, а також підвищенню рівня використання будівель та якість життя їх мешканців. Результати досліджень показали різке зменшення кількості незадоволених станом внутрішнього повітряного середовища після термомодернізачії. Підвищення комфорту та безпеки використання важливо особливо для людей похилого віку, які часто є більшістю мешканців будинків з особливо несприятливими енергетичними параметрами.
\end{abstract}

Ключові слова: енергоспоживання, енергоефективність, забруднення повітря, мікроклімат приміщенні.

\section{УДК 699.86:697.1:696.48}

\section{Оценка эффектов снижения потребления энергии на отопление зданий}

\author{
А. Лис \\ к.т.н.,. Ченстоховский политехнический университет, Ченстохова, Польша, anna.lis@pcz.pl, ORCID: 0000-0001-9497-5754
}

Аннотащия. Сохранение текущего уровня производства и стандартов жизни при бережном отношении $к$ окружающей среде и обеспечении хорошего здоровья общества возможно благодаря раииональному управлению энергоресурсами и правильному формированию энергетической характеристики возводимых зданий, а также улучшению энергетической характеристики существующих зданий. Суть реализачии программы глубокой термомодернизации существующих зданий заключается в достижении не только экономических, но и экологических, функииональных, сочиальных, интеграционных и других положительных результатов. Около 70 \% энергии в зданиях используется для отопления и подогрева горячей воды. Домашние хозяйства являются крупнейшими потребителями теплоты. В статье анализируется влияние снижения потребления теплоты на эксплуатационные нужды. Основные экономические эффекты термомодернизации, связаны с сокращением потребления топлива, воды и электроэнергии, а следовательно, финансовыми расходами. Приведённые эффекты также связаны с уменьшением загрязнения воздуха, улучшением условий микроклимата в помещениях и безопасности жителей, а также устранением энергетической бедности и повытением осведомлённости общества в области энергоэффективности.

Ключевые слова: энергопотребление, энергоэффективность, загрязнение воздуха, микроклимат помещении.

Надійшла до редакції / Received 02.03.2020 